\title{
Heroic Waste: Walpole, Ridicule and the Heroic in Early Eighteenth-century British Caricature
}

\section{Stefanie Lethbridge}

In early March 1730/31 the painter and engraver William Hogarth started circulating the subscription tickets for his now famous series of engravings the "Harlot's Progress". The ticket showed an etching with classical iconography of three boys as putti and the figure of Nature as Diana multimammia of the Ephesians. "Boys peeping at nature", thus the title of the print, was, as Ronald Paulson put it, "a come-on, an elaborate joke, and a statement of theory." It pinpoints neatly early eighteenth-century concerns about the relation of art to nature or the world, that is to say, questions of mimesis or imitation: what rules to use, what to show and what to disguise when imitating nature. In Hogarth's print one of the boys is painting this classical representation of nature, cutting her off at waist level. Another of the boys has in fact turned his back on the model, drawing or etching without directly consulting the original. A third boy seems to be arguing with a satyr whether or not to lift the piece of cloth that has been decorously draped across nature's lower parts. The satyr, embodying both satire (via the Greek satyra) and animal sexuality, ${ }^{2}$ transgresses eighteenth-century decorum but in fact tries to get much closer to nature than the other two more decorously distanced boys. The print illustrates how "[a]s an imitator of nature $[\ldots]$ an artist can expurgate Nature, ignore her altogether, present her unadorned, or create a tension of dress/undress." ${ }^{3}$ The dispute between putto and satyr, representatives of art according to the rules of the academy and of satire, ${ }^{4}$ assigns satire the role of unveiling the less decorous truths about nature. ${ }^{5}$

1 R. Paulson, Hogarth. The "Modern Moral Subject" 1697-1732, New Brunswick 1991, p. 275.

2 The English tradition of satyr relies on Roman mythology which conflated the Greek god Pan with the faunus and depicted the satyr with goat's haunches and hooves as well as horns, see P. Michel, Satyrn, in: P. Michel (Ed.), Spinnenfuß und Krötenbauch. Genese und Symbolik von Kompositwesen (Schriften zur Symbolforschung; 16), Zürich 2013, pp. 87-98, here p. 87. For the identification of satyrs with the literary genre satire see R. Quintero, Understanding Satire, in: R. Quintero (Ed.), A Companion to Satire. Ancient and Modern, Malden 2007, pp. 1-11.

3 Paulson, Hogarth (footnote 1), p. 276.

4 J. Döring, Eine Kunstgeschichte der frühen englischen Karikatur, Hildesheim 1991, p. 81.

5 Hogarth had used a similar motif of satyrs 'unveiling' truth in the frontispiece to another work of satirical use of classical models, Charles Gildon's adaption of Apuleius in "New Metamorphosis" (1724). For earlier uses of this motif see J. Czaplicka, Zur Herausbildung satirischer Methoden bei Hogarth, in: K. Herding / G. Otto (Ed.), Nervöse Auffangsorgane des inneren und äußeren Lebens. Karikaturen, Gießen 1980, pp. 31-86. 
Mimesis, or imitatio, remained a major tenet in early eighteenth-century aesthetic theory. In its standard formulation for poetry, imitating nature meant imitating classical models: "Learn hence for Ancient Rules a just Esteem;/To copy Nature is to copy Them" as Pope has it. ${ }^{6}$ Imitating classical models, however, proved problematic in the early eighteenth century, as it seemed difficult to adapt the classics, both their heroes and their artistic forms, to the needs and interests of an increasingly modern, commercial and socially mobile society. The poets retreated to satirical inversions of classical models: mock-heroic, mock-pastoral or mock-georgic. ${ }^{7}$ In the visual arts Hogarth states his rejection of the classics most emphatically in the manuscript for his treatise "The Analysis of Beauty" (1753):

"I could not help thinking that this [Hogarth's] way of painting might [...] become [...] more usefull and entertaining in this Nation than by the Eternal proposition of beaten subjects either from the Scriptures or from the old ridiculous stories of the Heathen gods $[\ldots] . "{ }^{\circ}$

In broadly generalised terms, early eighteenth-century aesthetic codes are characterised by a tension between efforts to draw on the imaginary dispositions provided by the classics and carving out new forms of artistic expression with contemporary relevance where the classics proved, more often than not, useful only as foil. As myth begins to lose its relevance for mimesis, satiric prints radically reduce aura, both of heroic models and, more so, of the imitator. The failed imitatio heroica in satirical prints unveils a society that has no room for the heroic apart from a nostalgia for a paradise of heroes, so clearly a paradise lost.

\section{The 'low' art of caricature}

The caricature or satirical print was one of those fairly new forms of expression that gained cultural currency in the early eighteenth century. Adapted from Dutch and French models, satirical prints actually established themselves late in Britain, but started to come into their own as a naturalized English form roughly from the 1720s and creating an 'age of caricature' in the second half of the century.9 "The Picture of Malice" (1710), a pamphlet on the Sacheverell trial, identified the "print, the canto and the libel grave" as chief weapons of propaganda. ${ }^{10}$ While many prints were produced for collectors, "others were pasted up at streetcorners and in ale-houses and gin-shops" and print-shop windows served as "pic-

\footnotetext{
A. Pope, An Essay on Criticism, lines 139-140.

7 Ulrich Broich develops this connection or rather dis-connection, U. Broich, Studien zum komischen Epos. Ein Beitrag zur Deutung, Typologie und Geschichte des komischen Epos im englischen Klassizismus 1680-1800 (Anglia; 13), Tübingen 1968, part 2, pp. 81-183. R. Paulson (Ed.), William Hogarth, The Analysis of Beauty, New Haven 1997, p. 123. The passage was rejected in the print version, see ibid., Introduction, p. xx.

9 Döring, Eine Kunstgeschichte der frühen englischen Karikatur (footnote 4), p. 66.

10 Quoted in W. A. Speck, Political Propaganda in Augustan England, in: Transactions of the Royal Historical Society, Fifth Series, 22, 1972, pp. 17-32, here p. 17.
} 
ture galleries of the public." 11 The press, which printed some of these caricatures, "played a crucial role in informing the people 'out-of-doors' [...] and in acting as the principal medium for the dissemination and articulation of popular protests against the government." 12 Jürgen Döring, in line with standard collections of prints, extends the definition of caricature to include prints, drawings or paintings that depict their topic satirically or humouristically and I follow this convention. ${ }^{13}$ This paper will focus on the much more rarely discussed caricatures of the early eighteenth century as the moment when functions of heroic myth as legitimisation of political power are (re-)negotiated.

A defining feature of the form is the attempt to devalue its topic, to create distance, to deflate, to unveil, to remove in other words the decorous piece of cloth draped around nature's lower parts. Contemporaries often rejected caricature as deliberately ugly and hence 'low', as does John Hughes in "The Spectator" who criticises "those burlesque pictures, which the Italians call Caracatura's; [which ...] transform the most agreeable beauty into the most odious monster." ${ }^{14}$ In their deliberate rejection of the codes of high art caricatures transgress rules of decorum. While classical rules of mimesis stressed the value of the general over the particular, the ideal over less than ideal reality (vide Aristotle) and the rational integration of parts into a whole, caricature offered deformity with the empiricist's love for detail, a firm anchoring in temporal and geographic concreteness and "above all, the submergence of the principal figures and flouting of rank" - all of which represented "blatant inversions of the code." ${ }^{15}$ Nonetheless, caricature lays claim to similar functions as 'high' art. As Carracci had put it, "a good caricature, like every work of art, is more true to life than reality itself." 16

Artistically not always highly accomplished and "disregarded by the dogmatic [though] loved by the public," 17 the satirical print is rewarding for the cultural critic in its close engagement with contemporary cultural issues. ${ }^{18}$ The textual or literary critic also finds that the visual representations in the satirical print are heavily invaded by textual material which at times disambiguates the potential polysemy of the image but more frequently adds further layers of meaning, thus

11 M. D. George, Hogarth to Cruikshank: Social Change in Graphic Satire, London 1967, p. 17.

12 H. T. Dickinson, Popular Politics in the Age of Walpole, in: J. Black (Ed.), Britain in the Age of Walpole, New York 1984, pp. 45-94, here p. 47.

13 Döring, Eine Kunstgeschichte der frühen englischen Karikatur (footnote 4), p. 24.

14 Spectator, 1712, Nr. 537.

15 D. Donald, The Age of Caricature. Satirical Prints in the Reign of George III, New Haven 1996, p. 28.

16 Quoted in E. H. Gombrich / E. Kris, Caricature, London 1940, p. 11.

17 Ibid., p. 3.

18 See for instance Brian E. Maidment who remarks that "in a key sense [prints belong] more to social history than to the history of art," B. E. Maidment, Reading Popular Prints 1790-1870, Manchester 1996, p. 5. 
complicating the meaning of the print by textual, intertextual and intermedial interferences.

In its engagement with the heroic, caricature creates and exploits a gap between the heroic (and that is to say the ideal and classical) model and a (real-life) imitation of this model that falls significantly short of this ideal. Per definition, caricature relies on imperfect even deformed repetition, it exploits the tensions between like and unlike. It highlights the discrepancy between the ideal and the real on the one hand by modes of excess that ridicule the heroic. On the other hand it turns mimesis into mimicry, exposing the imitation as meaningless pose, in fact undermining the function of the heroic model in carnivalesque inversions. In both cases caricature deliberately limits, even eliminates the aura that attaches to the heroic model or the (de-)heroized imitator of that model.

\section{Modes of excess}

Excess is a characteristic of the heroic: the hero stands out, he (usually he) is more courageous, more dedicated, more valorous than the average person. This excess is not always palatable; heroes are transgressive and often troublesome. ${ }^{19}$ The extraordinariness of the heroic is frequently visualised through forms of monumentalisation, by elevation or sheer size. Eighteenth-century satire, both textual and visual, takes this extraordinariness of heroic achievement to extremes and turns it into grotesque.

Lemuel Gulliver, in Jonathan Swift's "Gulliver's Travels" (1726), on his voyage to Lilliput is turned into a powerful agent by sheer size. He can turn this to good use when in a heroic moment he single-handedly extinguishes the disastrous fire in the royal palace by urinating copiously on it. While this action has the desired effect - putting out the fire - the queen is not amused: Nothing truly virtuous can be achieved by foul means. Gulliver has to flee the country. A Hogarth print of 1726, entitled "The Punishment of Lemuel Gulliver" and later reissued as "The Political Clyster" (Fig. 1), offers a variation of the story and Ronald Paulson calls it "the first mature 'political cartoon' in England." 20 The depiction is aimed at Robert Walpole's ministry and an England in decline - as was Swift's text. Gulliver is punished for his crime of befouling the queen's chambers by the application of an enema. He is purged of excess, in this case excessive waste matter. Both church and state officiate at this purging, the minister carried in a thimble and a clergyman preaching from a chamber pot which serves as his pulpit: "they are shown supervising this purging of a heroic and harmless Gulliver while ignoring

19 See W. Dinkelacker, Der alte Held. Belege aus mittelalterlicher Heldendichtung und ihr kulturhistorischer Quellenwert, in: E. Vavra (Ed.), Alterskulturen des Mittelalters und der Frühen Neuzeit (Veröffentlichungen des Instituts für Realienkunde des Mittelalters und der Frühen Neuzeit; 21), Wien 2008, pp. 183-202, here p. 201.

20

Paulson, Hogarth (footnote 1), p. 167. 


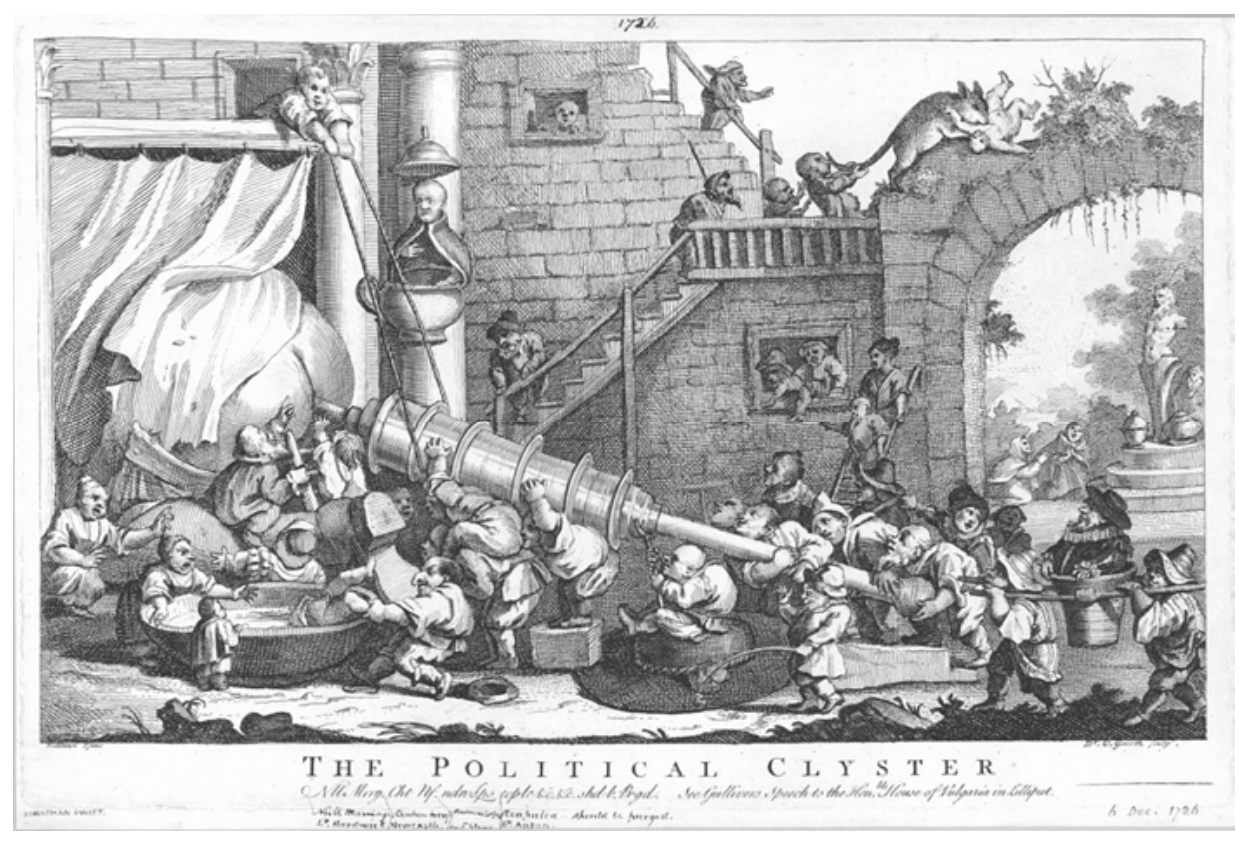

Fig. 1

William Hogarth, The Political Clyster, 1726 [1757], London, British Museum, Inv. No. BM 1797

the rats who devour their children and the term of Priapus being worshipped by their backsliding congregation." 21 Gulliver's heroic status is here communicated by the context of the story and his sheer size, it is at the same time radically undermined by showing the wrong body part in a humiliating position, just like Gulliver used the wrong means to extinguish the fire; his enormous posterior makes him grotesque rather than heroic. The fuzzy boundaries however, between putrefaction and purification, the unclear division between what is really value (putting out the fire) and foul waste (soiling the queen's chamber), between Gulliver's punished act that was really an act of rescue and the unattended real threat of rats carrying off the children, serve to question the constructions of value and waste more generally.

The eighteenth century, an expanding consumer society, was in fact acutely aware of the connection between value and waste - both signs and consequence of affluence: only abundant value made it possible to produce abundant waste. ${ }^{22}$ Waste products might even be accounted the fertile basis of prosperity: "There's many a tulip raised from dung" as Swift put it in "The Lady's Dressing Room."

21 Ibid., p. 166.

22 S. Gee, Making Waste. Leftovers and the Eighteenth-Century Imagination, Princeton 2010, pp. 37-39. 
Hogarth as well as Swift (and Pope and Milton before them) plays with the fact that "ontologically distinct categories share the property of excess that makes them superficially interchangeable [...] he allows the distinct attributes of waste and value to collapse into each other." 23 In extension of this ontological overlap between value and waste in terms of excess, caricature frequently inverts the excess of heroic greatness into an excess of filth. Thus, eighteenth-century satirical prints (and literature) explore literally the backside(s) of greatness; it is an overdetermined greatness, the great man is great everywhere, also in his waste products. Eighteenth-century prints abound in cheerful bawdy as well as malevolent obscenity, in bare bottoms (see for instance George Bickham's "Idol-Worship" depicting Walpole as Wolsey, Fig. 2), in great men or women urinating or defecating onto other people and in political leaders that physically evacuate - front and back - their enemies. Such outspoken, abusive and openly scatological depiction of the 'great and the good' amazed foreign visitors. Making their rulers turn the other cheek became part of British self-perception, functioning "as an assertion of defiant independence and protest against government" at a time when "the extension of political information, debate and assertiveness [reached] ever widening circles of British society." 24 On the other hand, one reason why the satirical print was continuously discounted as a low art form was precisely this preference for coprophilic indulgence and crude tavern humour. Thus Gerard de Lairesse's "Art of Painting", translated in 1738, derided low depictions of "Beggars, Oscenities, a Geneva-stall, Tobacco-Smoakers, Fidlers, nasty Children easing Nature and other things more filthy." 25

As an immediate effect the transgressions of caricature diminish aura, both of the work of art and of the person depicted. Brian Maidment describes Walter Benjamin's terms of analysis as one of the most useful "conceptual starting places for the study of prints." 26 Not only the means of mechanical reproduction and comparatively widespread distribution, which, though not a product for mass consumption yet, ${ }^{27}$ made the satirical print far more accessible than single paintings, but also the deliberately deflating representation of its subjects, eliminate aura. The ridicule which caricature evokes reduces distance, it makes the (potential) hero common in both senses of the word. Filth crosses the boundary between high and low, renders the division less certain, and while the caricature thus brings the hero low, it also brings him closer to home. An important tool in

23 Ibid., p. 99.

24 Donald, The Age of Caricature (footnote 15), p. 1.

25 Quoted in ibid., p. 18.

26 Maidment, Reading Popular Prints (footnote 18), p. 24, endnote 3.

27 Paul Langford identifies the market of prints "with the market for the products of Grub Street generally, that is to say the great mass of middling people involved in trade, industry or the emerging professions," P. Langford, Walpole and the Robinocracy, Cambridge 1986, p. 29; Donald, The Age of Caricature (footnote 15), pp. 20-21 also emphasizes the role of cheap copies in distributing the more famous satirical images. 


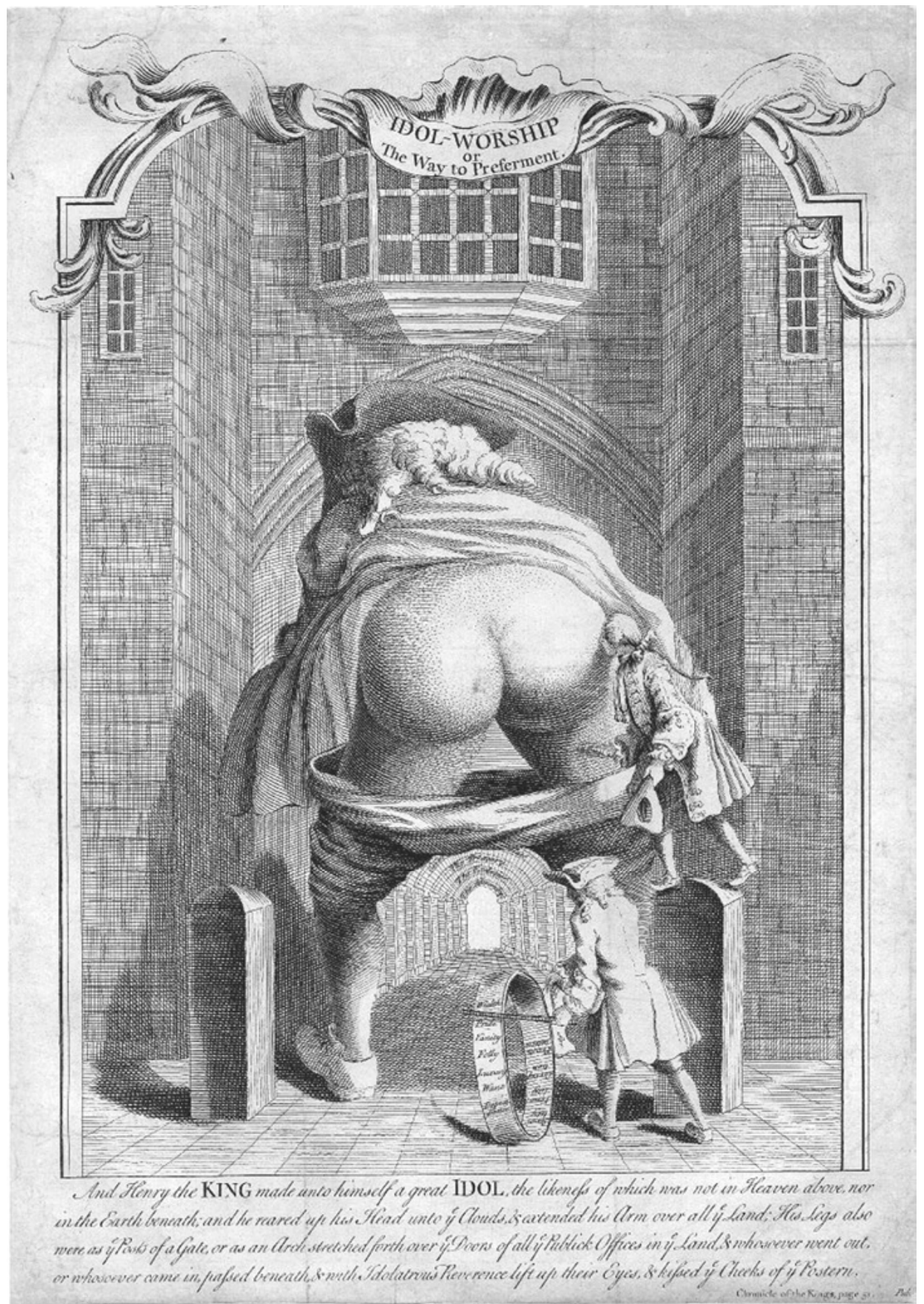

Fig. 2

George Bickham, Idol-Worship, 1740, London, British Museum, Inv. No. BM 2447 
the political propaganda wars of the early eighteenth century, the satirical print contributed to the shaping of the national imaginary and to the terms of political discussion. It also tested the practical uses of heroic greatness.

As Richard Terry has pointed out, the eighteenth century did not think of virtue and vice as necessarily opposites, but as two sides of the same coin, as elements on a continuum where a balanced and well regulated version represented virtue, while any form of extreme represented vice. ${ }^{28}$ Henry Fielding for instance, in the periodical "The Champion" pointed out the harmful potential of an excess of virtue: "For Virtue itself, by growing too exuberant, and [...] by running to Seed changes its very Nature, and becomes a most pernicious Weed of a most beautiful Flower." 29 Thus excessive modesty turns into prudery, excessive good manners into fussy ceremony etc. - any positive excess is problematic.

By way of a first conclusion it can thus be noted that the eighteenth-century satirical print - as did eighteenth-century literature - explores the effects of an overproduction of greatness which as a result turns grotesque and starts to demystify a heroic code relying on classical models and ideas of greatness in terms of extraordinariness and excess. The treatment by Swift and Hogarth suggests that the bold measures of the hero are punished in a culture intent on moderation. The merely partial and inflexible view of a church and state depicted by Hogarth who cannot see past their own rules and preconceptions, fragments the hero and classifies as transgressive what is actually beneficial. The moment of carnivalesque misrule, turning the great man bottom up, interrogates the cultural divisions between value and waste and conceptual hierarchies. "In the classical discursive body," as in the rules of eighteenth-century decorum, "were encoded those regulated systems which were closed, homogenous, monumental, centred and symmetrical." By contrast, the grotesque body has many orifices, it "is never closed off," evacuating body fluids it is open to processes of exchange and eventually also to change. ${ }^{30}$ While the (potential) hero loses aura, he also loses remoteness. The caricature's inversion of classical codes breaks rules in order to open discussion.

So far, one might well object, this has only a very vague connection to imitatio heroica in the narrower sense of the word, someone depicted as imitating or perhaps emulating not only general ideas of the heroic but a specific hero. I thus turn to a consideration of more specific allusions to a heroic model.

\section{Mimesis into mimicry}

In direct engagements with specific models of the heroic in satirical prints, the emulator or imitator is frequently exposed as unheroic. The employment of clas-

28 R. Terry, Mock-Heroic from Butler to Cowper, Burlington 2005, pp. 128-129.

29 The Champion, March 1739-40, quoted in Terry, Mock-Heroic (footnote 28), p. 129.

30 P. Stallybrass / A. White, The Politics and Poetics of Transgression, London 1986, p. 22. 
sical analogues was partly a ruse to avoid libel laws, ${ }^{31}$ since it was open to interpretation, but it also, and more importantly, interrogates the viability of imitating these heroes in a modern society based on commerce. In the case of satirical parallels to heroic figures from classical antiquity - myth or history - the heroic form is evoked, but the substance turns out to be hollow. To illustrate this, I focus on a number of prints from the context of the rule of Robert Walpole.

"The Stature of a Great Man, or the English Colossus" (Fig. 3) is one of the best known pieces by George Bickham. It appeared in 1740 at the price of $6 \mathrm{~d}^{32}$ and was, according to Döring, the companion piece to "Idol-Worship," showing the front side of a man of unusual greatness. ${ }^{33}$ Walpole is recognizable by the attribute of the garter, commonly used in contemporary caricature to denote him. ${ }^{34}$ 'The Great Man' was one of Walpole's many contemporary nicknames used both in an affirmative and an ironical sense. ${ }^{35}$ If anyone remained in doubt, the print also provides a label underneath the figure. Unlike "Idol-Worship," this is not immediately recognizable as satire. Walpole stands literally as a great man on two woolpacks, the main caption describes him as "The Stature of a Great Man, or the English Colossus." The description at the bottom outlines the dimensions and costliness of the colossus of Rhodes and concludes: "every Stature since of an unusual Magnitude is call'd Colossus." So far so great - it is the detail that exposes this monumentalisation as imposition. The fine print invades the image and destabilizes the visual greatness, attacking Walpole's reluctance to enter into war to prevent continuous Spanish disruptions of British sea trade. ${ }^{36}$ Walpole's sword for instance has the superscription "for peace." The badge attached to Walpole's ribband of knighthood instead of St. George slaying the dragon shows a fox, the emblem for Cardinal Fleury, who supposedly influenced Walpole. The ribbon coming from his pocket, marked as the "Sinking Fund" which was supposed to cover the National Debt, is inscribed: "You'll ask where is the gold I've swept? Why half is spent the rest I've kept," which accuses Walpole of corruption (not an original complaint - Walpole was notorious for running a corrupt system). The ships in the harbour are vanquished, one says "Must Submit" as it is sinking, another one in full sail has a flag "All Blown." "Commerce," represented

31 Speck, Political Propaganda in Augustan England (footnote 10), p. 31.

32 F. G. Stephens, Catalogue of Political and Personal Satires [...], vol. 3, Part 1, 1734-1750, London 1877 (Repr. London 1978), p. 351.

33 Döring, Eine Kunstgeschichte der frühen englischen Karikatur (footnote 4), pp. 143-144.

34 Walpole had declined a peerage in 1723 in order to remain in the Commons but had accepted an Order of Bath in 1725 and an Order of the Garter in 1726. He was known to be inordinately pleased with these distinctions; see J. Hoppit, A Land of Liberty? England 1689-1727, Oxford 2000, p. 409. On the whole, early caricature did not aim for life-like portraits, see Langford, Walpole and the Robinocracy (footnote 27), p. 19.

35 E. Pearce, The Great Man. Scoundrel, Genius and Britain's First Prime Minister, London 2007, p. 428.

36 N. Rogers, Resistance to Oligarchy. The City Opposition to Walpole and His Successors 1725-47, in: J. Stevenson (Ed.), London in the Age of Reform, Oxford 1977, pp. 1-29. 


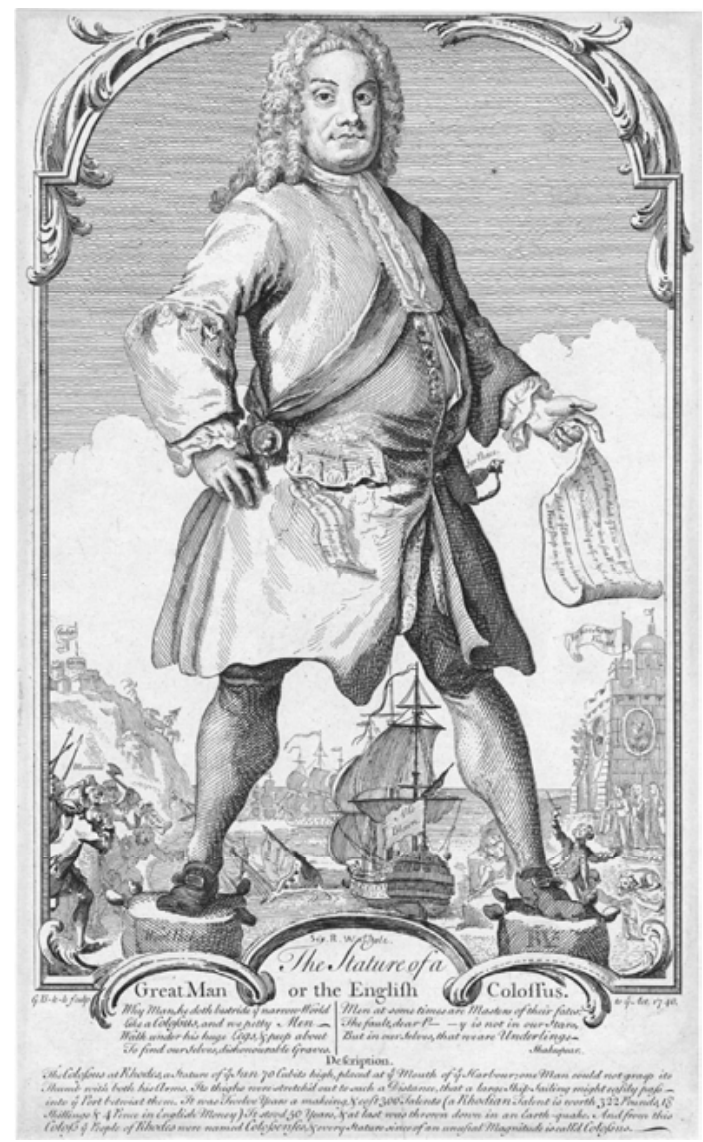

Fig. 3

George Bickham, The Stature of a Great Man, or the English Colossus, 1740, London, British Museum, Inv. No. BM 2458

by a merchant, sits helplessly at the shore. In the middle distance a group of merchants carry a petition which is inscribed "Not Heard" and at their feet lies "Magna f[art]a." Without following out all the details, the point should be clear: the words on the ribbons counteract the superficial claim of greatness made in the visual representation. The final blow comes in the smaller captions. The first one is a quote from Shakespeare's "Julius Caesar"

"Why, man, he doth bestride the narrow world

Like a Colossus, and we petty men

Walk under his huge legs and peep about

To find ourselves dishonourable graves.

Men at some time are masters of their fates:

The fault, dear P----y, is not in our stars,

But in ourselves, that we are underlings." 


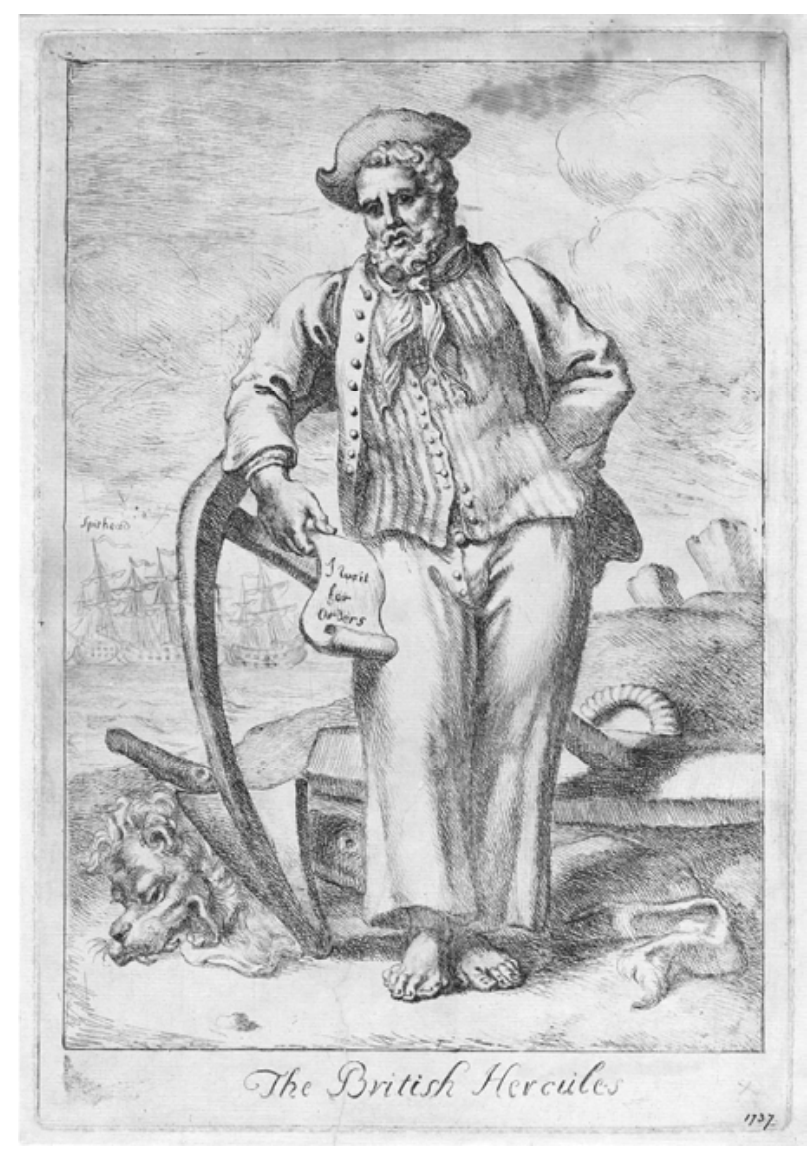

Fig. 4

Anon., The British Hercules, 1737, London, British Museum, Inv. No. BM 2332

This speech by Cassius tests Brutus' willingness to join the assassination plot. Pulteney, the leader of the Whig opposition, replaces Brutus in this quote. Comparing Walpole to Caesar has an ambiguous impact. In theory Caesar is a hero and described as such, for instance in Steele's "Tatler" (e.g. Nr. 81). He is, however, also a cultural code for tyrant which seems to be what is aimed at here, especially in the appeal to the opposition to stop submitting to the dishonour the colossus imposes. ${ }^{37}$ The fact-laden description of the Colossus at the very bottom of the print also hints at corruption: The Colossus "cost 300 Talents (a Rhodian Talent is worth 322 Pounds, 18 shillings \& 4 Pence in English Money).”

37 The image of the colossus as tyrant was later reused for instance for Lord Bute, see H. M. Atherton, Political Prints in the Age of Hogarth. A Study of the Ideographic Representation of Politics, Oxford 1974, pp. 219-222. 
The minute detail of the conversion of talent into money ironically questions the use that Walpole put his own talents to.

Walpole's visual alignment with heroic magnitude and its destabilisation through verbal interference and intertextual allusion in this print serves to satirise Walpole's position as great man; it shows, to return to the preoccupations of my first section, how much 'crap' lies behind supposed greatness, "that the great men [...] were not all they seemed to be." ${ }^{\prime 3}$ The political drift of the print is in favour of heroic action that was not forthcoming (harsher measures against Spain). The print exposes Walpole's greatness as an 'empty' greatness, as tyranny and - worse - directed by foreign powers against British liberties, hence Magna Carta dropped to the ground as "Magna $\mathrm{f}-\mathrm{a}$." Once again, this is the 'wrong' kind of greatness, an empty performance: however great it looks, this is both imposture and imposition.

Walpole's politics were not in fact susceptible to old-fashioned hero-mongering:

"He had no wish to be an equestrian statue in his own lifetime. The stupidity and expense of invading a territory for the glory of this monarch or that nation, the sheer teenage bombast of it, left Walpole in creditable disbelief. [...] He was a commercial civilian who understood profit and loss and derided trumpet and drum."39

Though some literary members of the patriot opposition laughed at George II's longing for traditional heroic achievement, notably Pope in his derision of "gun, drum, trumpet, blunderbuss and thunder" in the "Imitations of Horace," the opposition campaign in the press liked to use established emblems, like Britannia or the British lion, to lament the decline of British liberties and virtues. "The charges against Walpole and the 'Robinocracy' were levelled at what were taken to be deliberate attacks on traditional values, customs and institutions." 40

"The British Hercules" (Fig. 4), an anonymous etching of 1737, also explores this theme, in this case focussing on the forced absence of heroic achievement by the common sailor through Walpole's unwillingness to engage in war. The connection to Hercules is made in the title of the print but also iconographically by the hero's attributes lion-skin and club and the posture of the sailor which imitates that of the Hercules Farnese. ${ }^{41}$ As in the previous example, the imitatio heroica is merely ascription and in practice not successful. The tension between visual and verbal meaning in this example works the other way round as the visual depiction makes the claim of the inscription "The British Hercules" look absurd: club and lion-skin are lying on the ground, the sailor is on shore not on his battleship that is lying inactive at Spithead, he leans against an anchor and is "waiting for orders" as the scroll in his hand announces. The lion is double-coded, indicating Hercules but

38 Ibid., p. 206. Atherton also suspects social envy at Walpole's social rise in this depiction by the opposition, ibid., p. 207.

39 Pearce, The Great Man (footnote 35), pp. 427-428.

40 Langford, Walpole and the Robinocracy (footnote 27), p. 17.

41 Stephens, Catalogue of Political and Personal Satires (footnote 32), p. 229. 
also the British Lion, forced into dishonourable inactivity here, almost pinned down by the force of the anchor on shore. ${ }^{42}$ The print uses a common pattern of contemporary satire: "the navy [...] following the practice of the patriot press, is always pictured as the unhappy but valorous victim of Walpole's policies, and the sailor as courageous, loyal and patriotic." ${ }^{33}$ Walpole, the anti-heroic, forces the common Briton to waste his heroic potential.

Stephan Oettermann has argued against a popular knowledge of the Herculesmyth in the early eighteenth century on the continent. ${ }^{44}$ For Britain, the case seems to be slightly different. Chapbooks for instance, widely available reading material with cheap woodcut illustrations, popularised Hercules, ${ }^{45}$ and the often republished and widely read popular romance "The Seven Champions of Christendom" (orig. 1596/7), presenting the glorious adventures of a group of Christian heroes, also draws on Hercules several times by way of comparison. ${ }^{46}$ Hercules may even have been a particularly apt hero for popular consumption as he also performed many of his deeds in a position of service. The frustrated alignment of the common sailor with a classical hero evokes categories of national self-perception but also repeats Hogarth's accusation that contemporary culture has no room for the heroic. The print reduces the aura of the heroic in two senses (not necessarily both negative): it democratises the hero, making him potentially available as identification figure for the common people. At the same time, it shows how this identification is (maliciously) prevented. The hero becomes an identification figure of (nostalgic) longing, a merely wished-for imitation, an ideal that remains unreachable.

My final example is a print situated within a complicated web of intertextual and intermedial relations that presents Robert Walpole as the new Hercules, "The Glory of the Right Honourable Sir Robert Walpole" (Fig. 5). This takes up a tradition which Friedrich Polleroß described as 'Hercule moderne,' a reinterpretation of the ruler's identification with Hercules, where the prince not only attains the perfection of the classical model but in fact surpasses it. ${ }^{47}$ The print appeared

42 Donald, The Age of Caricature (footnote 15), pp. 47-50 as well as Langford, Walpole and the Robinocracy (footnote 27), pp. 15-19, point to the continued use of emblems in early eighteenth-century prints.

43 Ibid., p. 25.

44 S. Oettermann, Herkules von der Peripherie her: Jahrmarkt, Circus, Puppenspiel, in: R. Kray / S. Oettermann (Ed.), Herakles / Herkules, vol. 1, Metamorphosen des Heros in ihrer medialen Vielfalt, Basel 1994, pp. 161-178.

45 Thus for instance the chapbook "Hercules of Greece, History of the Life and Glorious Actions of the Mighty," published in Aldermary and Bow Churchyards, see J. Ashton, Chapbooks of the Eighteenth Century, London 1882, p. 485.

46 For the wide circulation of "The Seven Champions of Christendom" throughout the seventeenth and eighteenth centuries, see J. Fellows (Ed.), Richard Johnson, The Seven Champions of Christendom, Aldershot 2003, Introduction, pp. xxiv-xxviii.

47 F. Polleroß, De l'exemplum virtutis à l'apothéose. Hercule comme figure d'identification dans le portrait. Un exemple d'adaptation des formes de représentation classiques, in: A. Ellenius (Ed.), Iconographie, propagande et légitimation, Paris 2001, pp. 49-76, here p. 73. 


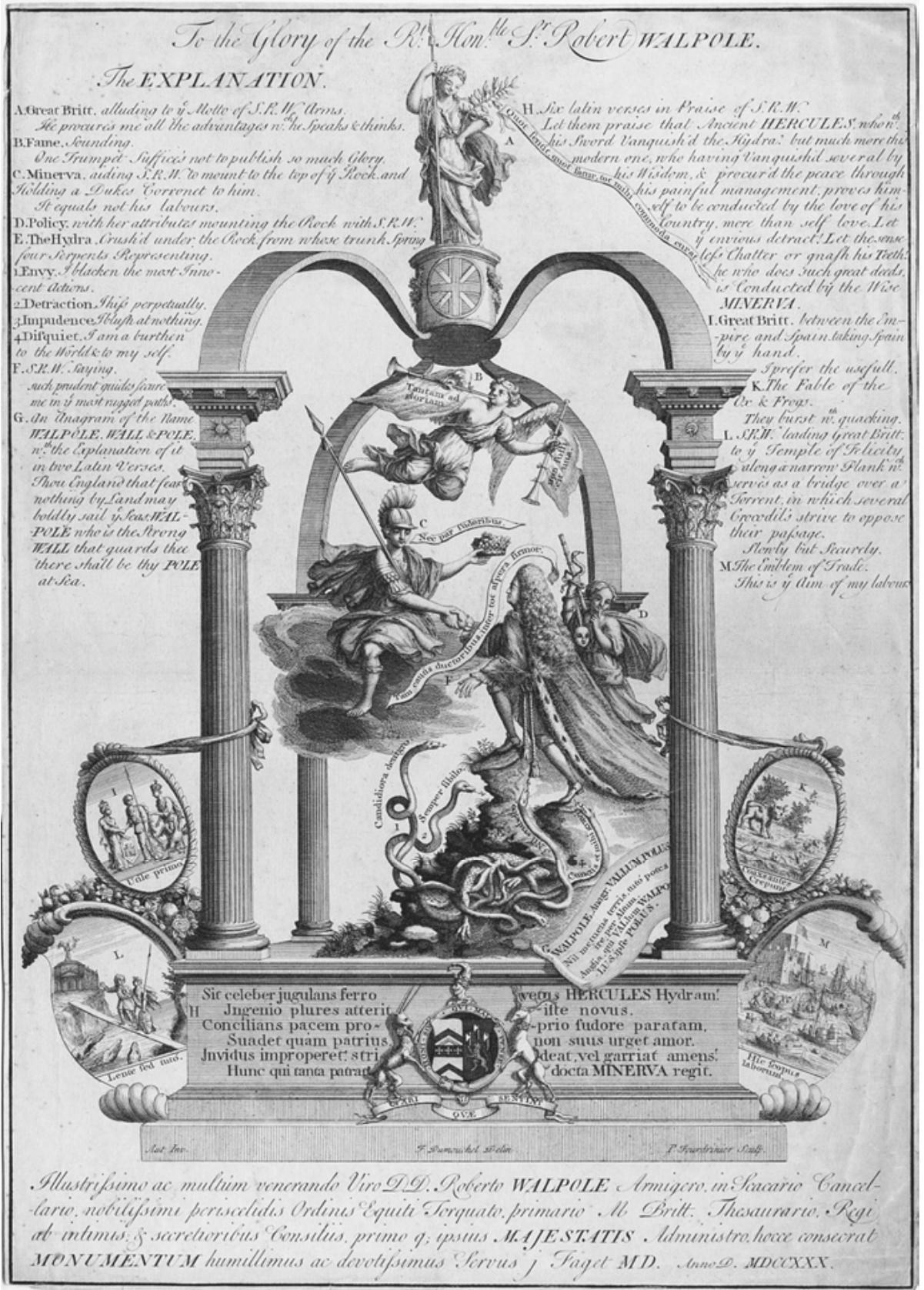

Fig. 5

Dumouchel / Faget / Fourdrinier, The Glory of the Right Honourable Sir Robert Walpole, (May?) 1730, London, British Museum, Inv. No. BM 1842 


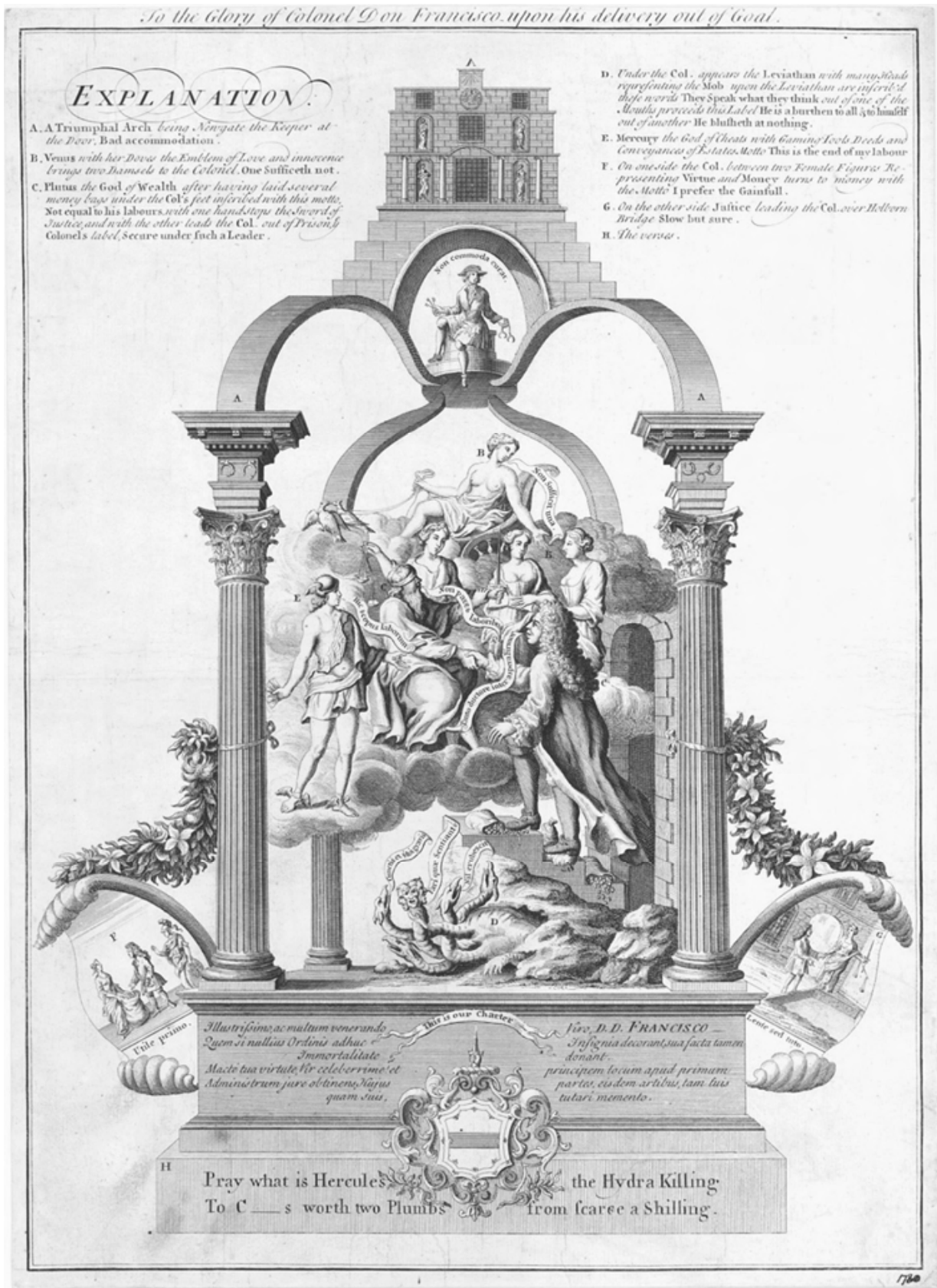

Fig. 6

Anon., To the Glory of Don Francisco, upon his Delivery out of Gaol, May or June 1730, London, British Museum, Inv. No. BM 1841 
early in 1730, the year Walpole attained undisputed political power after his previous ally Charles Townshend had been forced to resign in May. ${ }^{48}$ The design was by F. Dumouchel and J. Faget, and engraved by Paul Fourdrinier, a fact that incited "The Grubstreet Journal" in July 1730 to scoff at this adulation by "three Frenchmen." 49

The engraving shows Walpole, having trodden down the Hydra of faction, in a temple-like structure crowned by Britannia, receiving a ducal crown by Minerva. His labours, as medallion M explains, concern trade - a double-edged achievement, as trade was not considered either heroic or even quite gentlemanly in the aristocratic sense. The Latin inscription at the bottom on either side of Walpole's arms, praises Walpole as the new Hercules: "Let them praise that ancient Hercules who with his Sword Vanquish'd the Hydra! But much more this modern one, [...]." 50

Frederick Stephens describes the print as panegyric and J. H. Plumb supports this view. ${ }^{51}$ Langford, on the other hand, remarks rather dryly, "[i]f it was meant seriously, the naivety and extravagance of this praise sadly misfired." 52 Certainly the print immediately spurned further productions which erased any panegyric intention. A print with the same design appeared, either shortly before or shortly after the Walpole version, entitled "To the Glory of Don Francisco upon his delivery out of Gaol” (Fig. 6) and commented on Francis Charteris' release from prison who had raped (not for the first time) a servant girl and - according to rumour - had escaped punishment through Walpole's intervention. ${ }^{53}$ Again the comparison to Hercules is made, but this Hercules clearly derives his valour from money only: at the parting of the ways he chooses money over virtue (medallion F), walking across money bags he secures his release from Pluto who restrains Justice, and the inscription makes it plain that Charteris easily surpasses Hercules' valour through his wealth: "Pray what is Hercules the Hydra Killing / To C----s worth two Plumbs from scarce a Shilling." ${ }^{54}$ As Walpole was frequently compared to Charteris, the similarity of the print design and the comparison of both to Hercules further connect Walpole to Charteris' venality and immoral exploitation of the weak. At this point the significance of the heroic model itself slips into ambiguity, as Hercules not only defeated monsters but could also be associated

48 Pearce, The Great Man (footnote 35), p. 249.

49 The Grubstreet Journal 28, July 16, 1730, quoted in F. G. Stephens, Catalogue of Political and Personal Satires [...], vol. 2, 1689-1733, London 1873 (Repr. London 1978), p. 716.

50 Translation: Ibid., p. 714.

51 Ibid., p. 715; J. H. Plumb, Sir Robert Walpole. The King's Minister, London 1960, p. 244.

52 Langford, Walpole and the Robinocracy (footnote 27), p. 58.

53 For an account of the trial and Charteris' connection to Walpole, see A. E. Simpson, Popular Perceptions of Rape as a Capital Crime in Eighteenth-Century England. The Press and the Trial of Francis Charteris in the Old Bailey, February 1730, in: Law and History Review 22.1, 2004, pp. 27-70. Charteris, as Simpson notes, was "vilified across the social spectrum," ibid., p. 31.

54 Langford, Walpole and the Robinocracy (footnote 27), p. 59. 
with gastronomic or sexual debauchery. ${ }^{55}$ In June 1730 the original and possibly panegyric engraving on Walpole appeared in "The Craftsman," an opposition periodical conducted for Bolingbroke and Pulteney. In two columns of letterpress that frame the image someone signed "W---polius" ironically endorses the design and thus ridicules Walpole's greed for power and money, as well as the foreign (unpatriotic) origin of the design. ${ }^{56}$ In 1731, "The Craftsman" designed a series of "Hieroglyphicks" as frontispieces for a collected edition which included this rendering of Walpole's ascent to glory as 'new Hercules' and which was also sold as a separate print. In this "Craftsman" remake, without the explicit connection to Hercules (either in the Hydra or the inscription), a rather sleepy Minerva offers a ducal coronet with a fool's cap on it. ${ }^{57}$ The inscription below the engraving predicts Walpole's fall and the design did in fact make a reappearance in 1741 shortly before Walpole lost his power. Walpole as new Hercules had become an emblem of his decline.

The complicated tangle of verbal and visual interrelation, of copy, adaptation and partial copy, changes the significance of the comparison to the classical hero from a model to emulate to an empty form, a supposedly 'one-size-fits-all' hero costume that by its proliferation and risibility starts to lose its significance and thus turns out to fit noone. At best it still works as foil to show the corruption of a modern age that nostalgically longs for the heroes it has lost. The multiple failures to imitate the classical heroic model turn mimesis into mimicry - I adopt the term from Homi Bhabha who describes as mimicry the imitation of the coloniser's cultural practices by the colonised..$^{58}$ This imitation is never complete, because the colonised can only ever be a more or less successful copy with the difference clearly visible, never identical to the coloniser. The always imperfect copy in effect also subverts the model by making it look ridiculous in its necessarily failed completion. Jacob Fuchs has described the relation of the eighteenth century to classical antiquity as a moment of colonisation and the mock-heroic as an effort to overcome or subvert the influence of the classical as cultural coloniser. ${ }^{59}$ In the case of the satirical prints I examined, the heroic model turns into a mere façade or mere ascription without substance: it is impossible for the modern subject to appropriate or approximate the model convincingly. Radically reducing heroic aura, in the end these satirical renderings expose the weakness of all imitatio heroica which is, after all, always a copy and never the 'real thing.' Though this

55 R. Kray, Wider ,eine engbrüstige Imagination'. Studien zur medien-, stoff- und motivgeschichtlichen Typogenese des Herakles / Herkules-Mythos, in: R. Kray / S. Oettermann (Ed.), Herakles / Herkules, vol. 2, Medienhistorischer Aufriß, Repertorium zur intermedialen Stoff- und Motivgeschichte, Basel 1994, pp. 9-129, here pp. 51-52. Stephens, Catalogue of Political and Personal Satires (footnote 49), p. 715.

57 Ibid., pp. 689-690.

58 H. K. Bhabha, The Location of Culture, London 1994.

59 J. Fuchs, Postcolonial Mock-Epic: Abrogation and Appropriation, in: Studies in the Literary Imagination 33.2, 2000, pp. 23-43. 
does not necessarily undermine the heroes themselves, it seems to question them as models. ${ }^{60}$ The meanings of imitatio heroica proliferate uncontrollably down a slippery slope of uncertain interpretations where the verbal questions the visual and vice versa, where value can easily turn into waste and virtue is just another name for vice. The "old ridiculous stories of the Heathen gods" as Hogarth had it, no longer work as colonisers of cultural codes, the classical hero as straightforward model is no longer viable.

\section{Acknowledgements}

Fig. 1-6 (C) Trustees of the British Museum.

60 Klaus Herding does not see a critical impact directed against antiquity itself - as opposed to contemporary conditions - in caricature until the end of the nineteenth century, see K. Herding, ,Inversionen'. Antikenkritik in der Karikatur des 19. Jahrhunderts, in: K. Herding / G. Otto (Ed.), Nervöse Auffangsorgane des inneren und äußeren Lebens. Karikaturen, Giessen 1980, pp. 131-171. 